Article

\title{
Corn Stover and Wheat Straw Combustion in a 176-kW Boiler Adapted for Round Bales
}

\section{René Morissette *, Philippe Savoie and Joey Villeneuve}

Agriculture and Agri-Food Canada, Soils and Crops Research and Development Centre, 2560 Hochelaga Blvd., Quebec City, QC G1V 2J3, Canada; E-Mails: philippe.savoie@agr.gc.ca (P.S.); joey.villeneuve@agr.gc.ca (J.V.)

* Author whom correspondence should be addressed; E-Mail: rene.morissette@agr.gc.ca; Tel.: +1-418-656-2131 (ext. 4875); Fax: +1-418-648-2402.

Received: 7 September 2013; in revised form: 19 October 2013 / Accepted: 23 October 2013 / Published: 4 November 2013

\begin{abstract}
Combustion trials were conducted with corn stover (CS) and wheat straw (WS) round bales in a $176-\mathrm{kW}$ boiler (model Farm 2000). Hot water $\left(80{ }^{\circ} \mathrm{C}\right.$ ) stored in a 30,000-L water tank was transferred to a turkey barn through a plate exchanger. Gross calorific value measured in the laboratory was 17.0 and $18.9 \mathrm{MJ} / \mathrm{kg} \mathrm{DM}$ (dry matter) for CS and WS, respectively. Twelve bales of CS (1974 kg DM total, moisture content of $13.6 \%$ ) were burned over a 52-h period and produced 9.2\% ash. Average emissions of $\mathrm{CO}, \mathrm{NO}_{x}$ and $\mathrm{SO}_{2}$ were $2725,9.8$ and $2.1 \mathrm{mg} / \mathrm{m}^{3}$, respectively. Thermal efficiency was $40.8 \%$. For WS, six bales ( $940 \mathrm{~kg}$ DM total, MC of $15 \%$ ) were burned over a 28 -h period and produced $2.6 \%$ ash. Average emissions of $\mathrm{CO}, \mathrm{NO}_{x}$ and $\mathrm{SO}_{2}$ were $2210,40.4$ and $3.7 \mathrm{mg} / \mathrm{m}^{3}$, respectively. Thermal efficiency was $68.0 \%$. A validation combustion trial performed a year later with $90 \mathrm{CS}$ bales confirmed good heating performance and the potential to lower ash content $(6.2 \%$ average $)$.
\end{abstract}

Keywords: corn stover; wheat straw; round bale; combustion; flue gas emission; calorific value; ash content; energy balance

\section{Introduction}

In Canada, the five major cultivated grains are wheat, canola, corn, barley and soybeans, with a total yearly production of $65 \mathrm{Mt}$ [1]. According to Lal [2], corn and soybeans have a straw/grain ratio 
of 1 , while it is 1.5 for wheat, barley and canola. Residual biomass production (straw and stover) is thus well above $70 \mathrm{Mt}$ per year. It is estimated that $30 \%$ to $60 \%$ of this amount may be harvested sustainably without affecting the future productivity of cropped areas [3].

Meanwhile, the use of crop residues as a solid fuel for energy has been discussed and analyzed for several decades. In 1981, Lockeretz [4] compared costs and benefits of using crop residues for energy. The author suggested renewable energy policies to be developed in close coordination with soil conservation programs. The issue still needs to be addressed today, especially for corn stover (CS) as an intensive crop [5-7]. Considering 30\% removal of stover and straw, a very large quantity of biomass ( $>20 \mathrm{Mt} / \mathrm{yr})$ is still potentially available for various applications such as cellulosic feedstock for distillation, food processing, co-firing, combined heat and power generation, hot water and building heating. In contrast with fossil fuels, crop residues are generally more dispersed over a large territory, have a high moisture content, a low bulk density, and a low heating value [8]. In many cases, decentralized usage of crop residues can be profitable in remote areas where natural gas or woody biomass are costly and not produced locally [9].

The use of crop residues as a solid fuel for heating can be implemented with existing technology on a small scale, as long as exhaust air quality is well controlled. However, combustion of such biomasses can cause different problems like fouling, slagging, bed material agglomeration, and premature corrosion of the furnace metallic components [10]. The high level of alkalis (chloride, potassium) in crop residues may lead to aerosol formation, resulting in ash melting temperature drop, fouling and emission issues. An additive like clay may help to reduce the alkali release from straw and CS [11]. Another way to achieve this, and lower the moisture content as well, is to harvest CS in the spring after winter washing [12].

The combustion of round bales of CS, cotton stalks and soybean residues was done in 1981 by Sumner et al. [13] for the purpose of grain drying. They observed mitigated success with CS because of its relatively high bale density compared to cotton stalks $\left(142 v s .99 \mathrm{~kg} / \mathrm{m}^{3}\right)$ and incomplete combustion of the bale core. Today, many efficient straw burners with power ranging from 35 to $5000 \mathrm{~kW}$ are commercially available, mainly manufactured in Europe.

A poultry (turkey) farm in Port Williams, Nova Scotia, Canada, recently converted a propane heating system to a biomass heating facility using round bales of straw [14]. As the farmer produces his own wheat and corn grain for feeding, a substantial amount of straw and stover is available. The combustion equipment was originally designed and recommended for cereal straw-type bales. The objective of this research was to evaluate the potential use of CS bales in the same boiler without major modifications. The experimental approach was to evaluate flue gas emissions, residual ash, and the energy balance of wheat straw (WS) and CS combustion in the Farm 2000 boiler designed for burning round bales.

\section{Material and Method}

\subsection{Biomass Boiler, Hydronics System and Barn Description}

The heating system consists of a straw bale burner that transfers energy to hot water up to $80{ }^{\circ} \mathrm{C}$ which is used to maintain warm temperatures in a poultry barn. The boiler is a Farm 2000 model 
BB254/2 (Teisen Products Ltd., Worcestershire, UK) that can hold up to two round bales of $1.52 \mathrm{~m}$ diameter and $1.22 \mathrm{~m}$ width (Figure 1a). The rated output power is $176 \mathrm{~kW}$ with two loads per day (four bales) according to the manufacturer. Bales are loaded with a tractor through a large frontal opening normally closed by a well-sealed door. Heat is transferred to a $3500-\mathrm{L}$ water jacket by a multi tube heat exchanger. Flue gas is exhausted by a $362-\mathrm{mm}$ diameter stack without any filtering system. The boiler includes a partially automated primary air controller. The fan and damper assembly is mounted on the front door (Figure 1b). Based on operator experience, the damper downward travel time and fan intensity are adjusted prior to combustion. For WS, the low speed fan setting and the damper downward movement were used during the first $20 \mathrm{~min}$, and then the full fan speed was utilized until the end of bale combustion. For CS, the low speed and damper downward movement were set at $40 \mathrm{~min}$, and then fan setting was adjusted at full speed until the end of bale combustion.

Figure 1. (a) The combustion chamber; and (b) a schematic of boiler's main components.

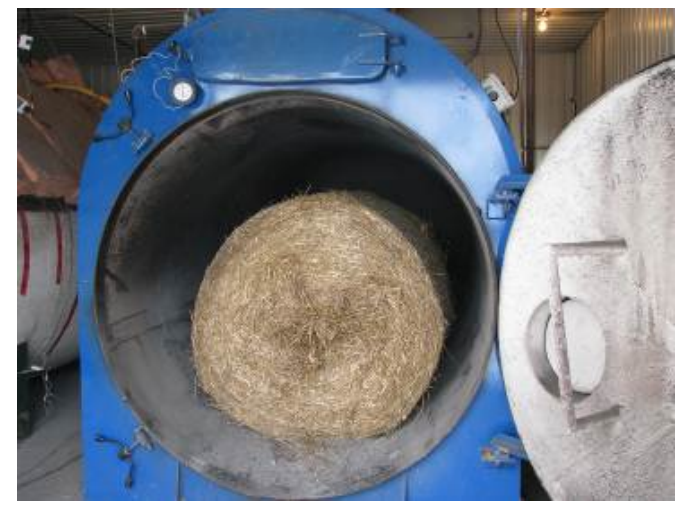

(a)

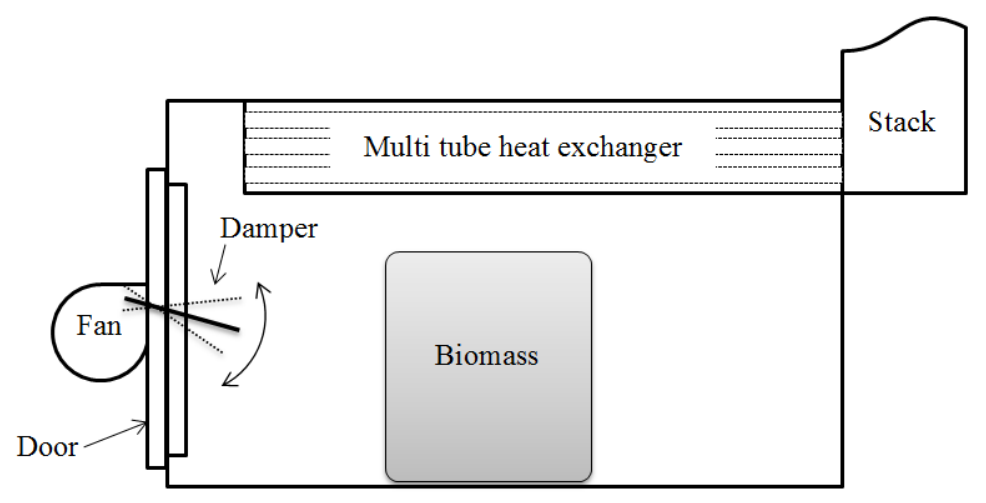

(b)

Hot water is stored in a 30,000-L water tank (2.45 m diameter, $6.5 \mathrm{~m}$ length) prior to being pumped through a $352-\mathrm{kW}$ plate exchanger where heat is transferred to the barn. The tank is partially insulated with six-inch rockwool (R24) on the upper half plus a Flex foil (R4) jacket on all surfaces of the tank. Water is pumped to the storage tank with a centrifugal pump (rated $18 \mathrm{~m}^{3} / \mathrm{h}$ at $65 \mathrm{kPa}$ head pressure). A similar pump delivers the water flow to the barn. All pipes are in steel except the underground high-density polyethylene (HDPE) pipes that link the boiler room to the barn network. A propane boiler is located in the barn for backup, for high heating demand periods and during biomass boiler maintenance.

The barn has two floors of $91.4 \mathrm{~m} \times 13.4 \mathrm{~m}$ for a total heated volume of $6541 \mathrm{~m}^{3}$. Each floor has six $22-\mathrm{kW}$ heat exchangers, each mounted with an axial fan, to maintain the set point temperature according to flock growing stage, humidity control and ventilation rate. Normal air temperature is $36{ }^{\circ} \mathrm{C}$ at day one, gradually decreases down to $19{ }^{\circ} \mathrm{C}$ at day 50 of turkey bird life and is maintained constant thereafter. Air exchange rate is about $2500 \mathrm{~m}^{3} / \mathrm{h}$ at day one and gradually increases up to $40,000 \mathrm{~m}^{3} / \mathrm{h}$ at day 70 for each floor. For each 77-day growing cycle, the barn can hold up to 14,000 turkeys (7000 per floor).

\subsection{Monitoring Devices}

Standalone data acquisition devices (HOBO logger from ONSET Corp., Bourne, MA, USA) were installed in different locations in the boiler room to measure water and air temperature and pump states 
(Figure 2). Water temperatures were taken with surface thermocouples at boiler exit (primary flow), boiler return, tank exit and tank return. Air temperatures were taken at the boiler intake (primary air) and inside and outside the boiler room. Relative humidity was also monitored inside and outside the boiler room. Primary air fan state and pump state were logged. Temperature, relative humidity and state were sampled every 5 min. Primary flow was monitored periodically using an ultrasonic flow meter (Hoskin Scientific, model DMTFH-12-A, Saint-Laurent, QC, Canada).

Figure 2. Schematic of the heating system (boiler room), probe location and description.

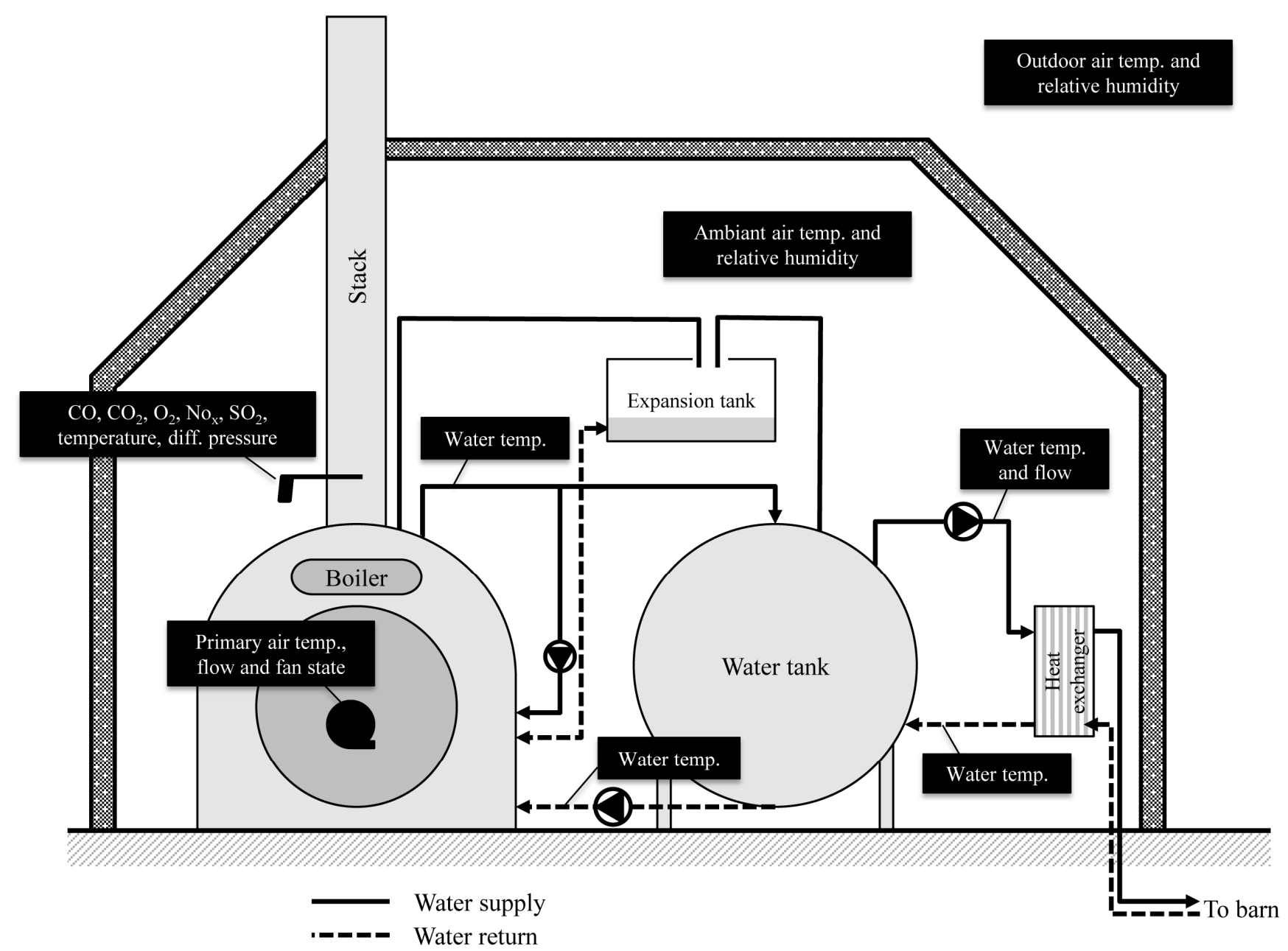

Flue gases were monitored with a portable combustion analyzer (Bacharach, model ECA 450, New Kensington, PA, USA). The gas sampling probe was located at the bottom of the stack and a temperature probe was mounted upstream in the boiler's primary air blower. Sampling rate was $5 \mathrm{~min}$. Measured parameters were oxygen $\left(\mathrm{O}_{2}, \%\right)$, carbon monoxide $\left(\mathrm{CO}, \mathrm{mg} / \mathrm{m}^{3}\right)$, nitric oxide $\left(\mathrm{NO}, \mathrm{mg} / \mathrm{m}^{3}\right)$, nitrogen dioxide $\left(\mathrm{NO}_{2}, \mathrm{mg} / \mathrm{m}^{3}\right)$, sulfur dioxide $\left(\mathrm{SO}_{2}, \mathrm{mg} / \mathrm{m}^{3}\right)$, flue gas temperature $\left({ }^{\circ} \mathrm{C}\right)$, and differential pressure (mbar). From these parameters, calculations were performed by the analyzer for $\mathrm{CO}_{2}(\%), \mathrm{NO}_{x}\left(\mathrm{mg} / \mathrm{m}^{3}\right)$, combustion efficiency (\%), and excess air ratio. The combustion efficiency is defined as the net calorific value ( $\mathrm{NCV}$ ) of the fuel minus the sum of heat losses in unburned components exiting the stack divided by NCV. The excess air ratio is the amount of air that exceeds the need for a stoichiometric combustion. 


\subsection{Biomass Characterization Prior to Combustion}

WS bales were harvested on the same farm where the boiler is located in Port Williams, Nova Scotia, Canada. They were formed with a fixed chamber round baler (Claas ROLLANT 250 without chopper, Claas, Harsewinkel, Germany) in fall 2011 and stored under shelter. Meanwhile, CS bales were harvested in spring 2011 in Sainte-Hélène-de-Bagot (Québec, Canada) according to a procedure developed by Lizotte and Savoie [15]. Because of the high moisture content of CS at grain harvest in late fall, which is between $35 \%$ and $50 \%$ [12] and the slow natural drying at that time of the year, stover was collected in the following spring to facilitate dry storage without further treatment after baling. Indeed, six months after grain harvest, a Hiniker model 5610 flail cutter-windrower (Hiniker Company, Mankato, MN, USA) collected from $30 \%$ to $50 \%$ of the residual corn fiber that had dried down naturally to less than $15 \%$ moisture. The stover bales were formed with a variable chamber round baler (New Holland 648, New Holland, PA, USA), stored under shelter and transported by truck in January 2012 to Nova Scotia.

Prior to combustion, every bale of WS and CS was weighed, measured (diameter and length), and sampled for moisture content (MC) determination, ash, and energy content. A sample of at least $100 \mathrm{~g}$ was extracted from each bale with a core probe $(31 \mathrm{~mm}$ diameter, $61 \mathrm{~cm} \mathrm{long})$. Samples were weighed in a paper bag and oven dried for $24 \mathrm{~h}$ at $103{ }^{\circ} \mathrm{C}$ for $\mathrm{MC}$ determination. Gross calorific value (GCV) and ash content were determined in the laboratory with a calorimeter (Parr 6100 Oxygen Bomb Calorimeter with 1108P Oxygen Combustion Bomb, Parr Instrument Company, Moline, IL, USA) to meet standard EN 14918:2009 [16]. Ash content was measured with an ash analyzer (LECO TGA701 Thermogravimetric Analyzer, LECO, St. Joseph, MI, USA), complying with standard ASTM D7582-10 [17].

\subsection{Combustion Procedure}

As the combustion rate depends on the heating needs and biomass properties, conservative assumptions were made to plan the experiment. According to the boiler operator, a single bale can provide heat for up to $4 \mathrm{~h}$. Within the limited time scheduled to perform the experiment and a definite number of bales available, six bales of WS within a 24-h period followed by twelve bales of CS within a 48-h period were burnt. Prior to each biomass type trial, the combustion chamber and the tube heat exchanger were cleaned while ashes were removed using a tractor front-end loader. Each bale was loaded in the combustion chamber at a distance between 1.25 and $1.5 \mathrm{~m}$ from the door. Primary air fan settings were adjusted according to the operation manual. Only one bale at a time was loaded and burned except during the night when two bales were placed typically at 11 p.m. until the next morning. During combustion trials, process air and water conditions, pump state, and flue gases were monitored continuously to ensure proper energy balance calculations. At the end of a trial (six WS bales or twelve CS bales), ashes were removed and weighed using a high capacity floor scale ( $0.2 \mathrm{~kg}$ resolution).

\subsection{Energy Balance Calculation}

An energy balance was calculated for each bale load as described by Equation (1). The total energy available from the bale load $\left(E_{F u e l}\right)$ was estimated from the NCV which is the GCV estimated 
experimentally and corrected for moisture content and hydrogen, as explained in Section 3.1 below. Temperature data were collected every $5 \mathrm{~min}$ in the boiler $\left(T_{B}\right)$, in the water tank $\left(T_{T}\right)$, at the hot water outlet $\left(T_{O}\right)$ and at the water return $\left(T_{R}\right)$ from the heat exchanger. An average water flow (m', in $\left.\mathrm{kg} / \mathrm{s}\right)$ was measured and a standard heat capacity was considered $\left(\mathrm{c}_{\mathrm{p}}, 4.18 \mathrm{~J} / \mathrm{g} /{ }^{\circ} \mathrm{C}\right)$. The energy loss $\left(E_{\text {Loss }}\right)$ was the sum of energy dissipated to the surroundings, the chimney stack and the ash box. These losses were not measured but estimated as a group from other terms. The change in stored energy in the boiler and in the tank was estimated as a function of mass of water ( $m_{B}$ and $m_{T}$, respectively) and temperature change during the combustion. The energy transfer was measured at each measurement interval $(i)$, for the total number of intervals $(n)$. The change in energy in the boiler and the tank need to be estimated simply between the first $(i=1)$ and the last $(i=\mathrm{n})$ interval. The energy balance equation can be expressed as follows:

$$
E_{\text {Fuel }}=E_{\text {Loss }}+m_{B} c_{P}\left(T_{B n}-T_{B 1}\right)+m_{T} c_{P}\left(T_{T n}-T_{T 1}\right)+\sum_{i=1}^{i=n} m^{\prime} c_{\mathrm{P}}\left(T_{O i}-T_{R i}\right) \Delta t_{i}
$$

Energy loss can be estimated since all other terms are measured and calculated experimentally.

\subsection{Combustion Validation Trials with CS}

A second set of combustion trials was done between January and April 2013 with 90 CS bales that were harvested on the farm in Nova Scotia during spring 2012. CS bales for the 2013 validation trial were formed with a fixed chamber round baler (Claas ROLLANT 250 without chopper) which resulted in lower density than bales used in the previous 2012 trial (which were formed with the variable chamber baler). Between spring 2012 and winter 2013, CS bales were stored under shelter. The purpose of this second set of trials was to validate combustion rate, ash content and ash rate removal. All bales were measured and weighed at harvest; they were weighed again just before being burned. One bale out of five was sampled for moisture content. No energy balance was performed during these validation trials. Ashes were collected and weighed after each trial which comprised 30 bales.

\section{Results and Discussion}

\subsection{Biomass Characteristics}

Table 1 reports average properties of WS and CS bales used for the January 2012 combustion trials. For WS bales, average moisture content and bale mass were $14.6 \%$ and $183.2 \mathrm{~kg}$, respectively. Bale diameter and width averaged $1.47 \mathrm{~m}$ and $1.20 \mathrm{~m}$, respectively, while average density was $77.1 \mathrm{~kg} \mathrm{DM} / \mathrm{m}^{3}$. For the CS bales, moisture content and mass averaged at $13.6 \%$ and $190.2 \mathrm{~kg}$, respectively. Diameter was $1.32 \mathrm{~m}$ and width was $1.15 \mathrm{~m}$. Thus, CS bale density was $104.5 \mathrm{~kg} \mathrm{DM} / \mathrm{m}^{3}$ and $35 \%$ higher that WS bale density.

All samples were analyzed in the laboratory for GCV and ash content. NCV was determined using Equation (2) [18], where $G C V$ units are $\mathrm{MJ} / \mathrm{kg}$ fuel (dry basis-d.b.); $w$ is moisture content in \% (wet basis - w.b.); and $h$ is concentration in hydrogen (5.5\% d.b. as estimated in the literature for straw and stover [19]). This equation is a good estimate for any woody and herbaceous biomass fuel: 


$$
N C V=G C V\left(1-\frac{w}{100}\right)-2.444 \cdot \frac{w}{100}-2.444 \cdot \frac{h}{100} \cdot 8.936\left(1-\frac{w}{100}\right)\left[\frac{M J}{k g}, w . b .\right]
$$

Table 1. Characteristics of wheat straw (WS) and corn stover (CS) bales measured in the laboratory.

\begin{tabular}{|c|c|c|c|c|c|c|c|c|c|}
\hline \multirow{2}{*}{ Parameter } & \multirow{2}{*}{ Unit } & \multicolumn{4}{|c|}{ WS (six bales) } & \multicolumn{4}{|c|}{ CS (twelve bales) } \\
\hline & & Ave. & S.D. & Min. & Max. & Ave. & S.D. & Min. & Max. \\
\hline Moisture content & $\%$ & 14.6 & 0.7 & 13.6 & 15.5 & 13.6 & 1.4 & 12.7 & 17.7 \\
\hline \multirow{2}{*}{ Bale mass } & $\mathrm{kg}$ & 183.2 & 13.7 & 166.6 & 198.6 & 190.2 & 12.4 & 163.4 & 206.8 \\
\hline & kg DM & 156.5 & 11.9 & 144.0 & 170.7 & 164.5 & 12.5 & 134.5 & 180.4 \\
\hline Diameter & $\mathrm{m}$ & 1.47 & 0.03 & 1.43 & 1.52 & 1.32 & 0.04 & 1.25 & 1.39 \\
\hline Width & $\mathrm{m}$ & 1.20 & 0.00 & 1.20 & 1.20 & 1.15 & 0.02 & 1.12 & 1.18 \\
\hline Volume & $\mathrm{m}^{3}$ & 2.04 & 0.09 & 1.91 & 2.16 & 1.58 & 0.11 & 1.40 & 1.76 \\
\hline \multirow{2}{*}{ Density } & $\mathrm{kg} / \mathrm{m}^{3}$ & 90.2 & 8.7 & 79.6 & 103.8 & 120.8 & 6.7 & 112.0 & 131.8 \\
\hline & $\mathrm{kg} \mathrm{DM} / \mathrm{m}^{3}$ & 77.1 & 7.6 & 68.8 & 89.2 & 104.5 & 6.3 & 96.1 & 114.2 \\
\hline Gross calorific value & $\mathrm{MJ} / \mathrm{kg}$ d.b. & 18.91 & 0.33 & 18.55 & 19.47 & 17.04 & 0.87 & 15.90 & 18.72 \\
\hline Net calorific value & MJ/kg w.b. & 14.77 & 0.23 & 14.54 & 15.07 & 13.35 & 0.74 & 12.51 & 14.98 \\
\hline Total gross energy & $\mathrm{MJ} /$ bale & 2955.9 & 188.7 & 2731.6 & 3167.5 & 2800.5 & 227.5 & 2422.1 & 3226.1 \\
\hline Total net energy & $\mathrm{MJ} /$ bale & 2702.7 & 169.9 & 2503.4 & 2894.4 & 2540.1 & 216.6 & 2189.9 & 2957.9 \\
\hline Ash content & $\%$ d.b. & 1.82 & 0.22 & 1.59 & 2.14 & 11.70 & 5.32 & 5.09 & 22.14 \\
\hline
\end{tabular}

GCV (MJ/kg d.b.) averaged 18.91 for WS and 17.04 for CS (Table 1). NCV based on average moisture content were 14.77 and $13.35 \mathrm{MJ} / \mathrm{kg}$ w.b., respectively. Ash content obtained with the thermogravimetric analyzer (TGA) was $1.82 \%$ for WS and $11.70 \%$ for CS. Ash for WS had a small range (1.59\% to $2.14 \%$ ) compared to CS (5.09\% to $22.14 \%)$. According to Van Loo and Koppejan [18], ash has a negative contribution to GCV. Analyses showed that the high ash content of CS resulted in a lower GCV compared to WS.

\subsection{Combustion Trials}

Six WS bales were burned from 15:40 on 23 January 2012 to 19:55 on 24 January 2012 (about $28 \mathrm{~h}$; Table 2). Bales were placed one at a time in the furnace except during the night when two WS bales were placed together (bales number S3 and S21). The average combustion time per bale was $280 \mathrm{~min}$ with an average burning rate of $33.52 \mathrm{~kg} \mathrm{DM} / \mathrm{h}$ for WS.

The $12 \mathrm{CS}$ bales burned over a period of $52 \mathrm{~h}$ from 20:00 on 24 January to 23:55 on 26 January. Average combustion time per bale was 9\% shorter compared to WS (255 vs. $280 \mathrm{~min}$ ) while CS bales were $5 \%$ heavier than WS bales (165 vs. $157 \mathrm{~kg} \mathrm{DM})$. The biomass burning rate was therefore $15 \%$ higher for CS than for WS (38.69 vs. $33.52 \mathrm{~kg} \mathrm{DM} / \mathrm{h})$. The higher burning rate of CS was partly related to the average lower exterior temperature $\left(0\right.$ vs. $\left.5.4{ }^{\circ} \mathrm{C}\right)$ during $\mathrm{CS}$ trial and the lower net calorific value of CS (13.35 vs. $14.77 \mathrm{MJ} / \mathrm{kg}$ w.b.).

The quantity of ash removed from the boiler is shown in Table 3 . It includes ash in the combustion chamber, in the heat exchanger and in the bottom stack. It does not include fly ash in the flue gas which was not monitored. Ash produced by the combustion of $48 \mathrm{WS}$ bales for normal heating (between 13 January 2012 and 23 January 2012) was weighed and identified as the "pre-combustion 
trial" (PCT). This PCT was followed by individual bale monitoring. Ash content of WS bales during the PCT was $1.70 \%$; it was $2.55 \%$ on average during the six individual WS bale combustion. These ash levels were comparable to the level measured in the laboratory (1.82\%). However, they were lower than those reported in the literature, which ranged from $2.69 \%$ to $13.5 \%$ d.b. with an average of $6 \%$ d.b. [19]. Ash production rates were 0.53 and $0.86 \mathrm{~kg} / \mathrm{h}$ for the 48 and $6 \mathrm{WS}$ bale trials, respectively. CS ash content after the 12-bale combustion trial averaged $9.17 \%$ d.b., which was lower than the TGA value (11.70\% d.b.). Various ash levels for CS are reported in the literature: $4 \%$ for standing stalk, unwashed [20] and 5.9\% for small stover bales harvested in the spring six months after grain harvest [21]. Higher values and variations observed for ash content of CS are probably linked to the harvesting method and soil contamination. Actually, the Hiniker mower-windrower tended to mix soil dust into the stover. The contamination depends on machinery operation, soil type and moisture, frost cover and distance of rotary parts from ground level. Ash production rate during the combustion of the $12 \mathrm{CS}$ bales averaged $3.5 \mathrm{~kg} / \mathrm{h}$, i.e., more than four times higher than ash production with WS bales. This implies that ash removal operations and multi tube exchanger cleaning will be more frequent with CS than with WS.

Table 2. Combustion trial loading sequence with burning duration and rate (2012 trials).

\begin{tabular}{|c|c|c|c|c|c|c|c|c|}
\hline Bale ID & $\begin{array}{l}\text { MC } \\
(\%)\end{array}$ & $\begin{array}{c}\text { Mass } \\
(\mathbf{k g})\end{array}$ & $\begin{array}{c}\text { Mass } \\
(\mathrm{kg} \text { DM) }\end{array}$ & $\begin{array}{l}\text { Start date } \\
\text { and time }\end{array}$ & $\begin{array}{l}\text { End date } \\
\text { and time }\end{array}$ & $\begin{array}{c}\text { Duration } \\
(\min )\end{array}$ & $\begin{array}{c}\text { Burning rate } \\
(\mathrm{kg} \mathrm{DM} / \mathrm{h})\end{array}$ & $\begin{array}{c}\text { Ext. temp. } \\
\left({ }^{\circ} \mathrm{C}\right)\end{array}$ \\
\hline \multicolumn{9}{|c|}{ WS } \\
\hline S1 & 14.4 & 193.2 & 165.4 & $01 / 23 \quad 15: 40$ & $01 / 2318: 55$ & 195 & 50.88 & 0.1 \\
\hline S2 & 14.0 & 198.6 & 170.7 & 01/23 19:00 & 01/23 23:15 & 255 & 40.17 & 2.0 \\
\hline S3 & 13.6 & 166.6 & 144.0 & $01 / 2323: 15$ & 01/24 09:35 & 620 & 29.93 & 5.5 \\
\hline $\mathrm{S} 21$ & 15.0 & 194.4 & 165.2 & \multicolumn{4}{|c|}{ Dual burning with S3 } & \\
\hline S4 & 15.1 & 174.0 & 147.8 & 01/24 09:40 & 01/24 13:45 & 245 & 36.19 & 11.2 \\
\hline S5 & 15.5 & 172.2 & 145.6 & $01 / 2413: 50$ & 01/24 19:55 & 365 & 23.93 & 8.3 \\
\hline Ave. & 14.6 & 183.2 & 156.5 & - & - & $280^{\mathrm{a}}$ & 33.52 & 5.4 \\
\hline Sum & - & 1099.0 & 938.7 & - & - & 1680 & - & - \\
\hline \multicolumn{9}{|c|}{$\mathrm{CS}$} \\
\hline $\mathrm{C} 6$ & 13.1 & 198.2 & 172.3 & $01 / 2420: 00$ & 01/24 23:30 & 210 & 49.22 & 5.8 \\
\hline $\mathrm{C} 7$ & 13.7 & 168.6 & 145.5 & $01 / 2423: 35$ & $01 / 2506: 25$ & 410 & 21.30 & 3.4 \\
\hline $\mathrm{C} 8$ & 12.8 & 190.0 & 165.7 & $01 / 2506: 30$ & $01 / 2510: 55$ & 265 & 37.52 & 3.3 \\
\hline $\mathrm{C} 9$ & 13.8 & 191.6 & 165.2 & 01/25 11:00 & $01 / 2514: 55$ & 235 & 42.18 & 4.1 \\
\hline $\mathrm{C} 10$ & 12.9 & 195.2 & 170.0 & 01/25 15:00 & 01/25 18:20 & 200 & 50.99 & 1.7 \\
\hline $\mathrm{C} 11$ & 12.8 & 206.8 & 180.4 & $01 / 2518: 25$ & 01/25 22:40 & 255 & 42.44 & -0.4 \\
\hline $\mathrm{C} 12$ & 13.9 & 199.0 & 171.3 & $01 / 2522: 45$ & 01/26 03:55 & 310 & 33.15 & -0.5 \\
\hline $\mathrm{C} 13$ & 13.8 & 190.4 & 165.2 & 01/26 04:00 & 01/26 07:45 & 225 & 43.79 & -3.3 \\
\hline $\mathrm{C} 14$ & 12.8 & 191.6 & 166.1 & 01/26 07:50 & 01/26 11:40 & 230 & 43.61 & -1.7 \\
\hline $\mathrm{C} 15$ & 12.7 & 197.4 & 172.4 & $01 / 2611: 45$ & $01 / 2615: 35$ & 230 & 44.97 & 0.0 \\
\hline $\mathrm{C} 16$ & 12.9 & 190.4 & 165.9 & $01 / 2615: 40$ & 01/26 20:40 & 300 & 33.18 & -6.0 \\
\hline $\mathrm{C} 17$ & 17.7 & 163.4 & 134.5 & $01 / 2620: 45$ & $01 / 2623: 55$ & 190 & 42.46 & -6.4 \\
\hline Ave. & 13.6 & 190.2 & 164.5 & - & - & 255 & 38.69 & 0.0 \\
\hline Sum & - & 2282.6 & 1974.4 & - & - & 3060 & - & - \\
\hline
\end{tabular}

\footnotetext{
${ }^{\mathrm{a}}$ : Average per bale.
} 
Table 3. Ash content from pre-combustion trial (PCT) WS and individually monitored WS and CS bales during January 2012 combustion trials.

\begin{tabular}{ccccccc}
\hline Biomass & Bales burned & $\begin{array}{c}\text { Mass } \\
\text { burned }\end{array}$ & $\begin{array}{c}\text { Accumulation } \\
\text { period }\end{array}$ & Ash and unburned content & Ash production rate \\
\hline- & - & $\mathrm{kg} \mathrm{DM}$ & $\mathrm{h}$ & $\mathrm{kg}$ & \% d.b. & $\mathrm{kg} / \mathrm{h}$ \\
\hline PCT WS & 48 & 7517 & 240 & 127.6 & 1.70 & 0.53 \\
WS & 6 & 938.7 & 28 & 24.0 & 2.55 & 0.86 \\
CS & 12 & 1974.4 & 52 & 181.0 & 9.17 & 3.48 \\
\hline
\end{tabular}

\subsection{Flue Gas Emissions}

Table 4 reports gas emissions during the 2012 combustion trials of some individually monitored bales, including supplementary WS bales S22 and S23.

Table 4. Flue gas emission measurements for WS and CS bale combustion.

\begin{tabular}{|c|c|c|c|c|c|c|c|c|c|c|c|c|c|}
\hline \multirow{2}{*}{$\begin{array}{c}\text { Bale } \\
\text { ID } \\
-\end{array}$} & \multirow{2}{*}{ 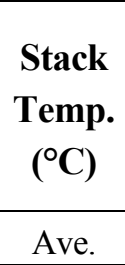 } & \multirow{2}{*}{$\begin{array}{c}\text { Intake } \\
\text { Temp. } \\
\left({ }^{\circ} \mathrm{C}\right)\end{array}$} & \multirow{2}{*}{$\begin{array}{c}\text { Mass } \\
\text { air } \\
\text { flow } \\
(\mathbf{k g} / \mathbf{s}) \\
\text { Ave. } \\
\end{array}$} & \multirow{2}{*}{$\begin{array}{l}\text { Eff. } \\
\text { (\%) }\end{array}$} & \multirow{2}{*}{$\begin{array}{c}\text { Excess } \\
\text { air } \\
\text { ratio } \\
(\%) \\
\text { Ave. } \\
\end{array}$} & \multirow{2}{*}{$\begin{array}{c}\mathbf{O}_{2} \\
(\%)\end{array}$} & \multirow{2}{*}{$\begin{array}{l}\mathrm{CO}_{2} \\
\mathbf{( \% )}\end{array}$} & \multicolumn{2}{|c|}{$\begin{array}{c}\mathrm{CO} \\
\left(\mathrm{mg} / \mathrm{m}^{3}\right)\end{array}$} & \multicolumn{2}{|c|}{$\mathrm{NO}_{x}\left(\mathrm{mg} / \mathrm{m}^{3}\right)$} & \multicolumn{2}{|c|}{$\begin{array}{c}\mathrm{SO}_{2} \\
\left(\mathrm{mg} / \mathrm{m}^{3}\right)\end{array}$} \\
\hline & & & & & & & & Ave. & Max. & Ave. & Max. & Ave. & Max. \\
\hline \multicolumn{14}{|c|}{ WS } \\
\hline S1 & 275.0 & 27.1 & 0.30 & 68.9 & 181 & 13.7 & 7.4 & 3533 & 7148 & 108.8 & 179.0 & 7.9 & 76.3 \\
\hline S2 & 249.3 & 30.8 & 0.27 & 70.2 & 110 & 15.1 & 10.0 & 1644 & 4622 & 58.3 & 121.4 & 1.8 & 6.9 \\
\hline S3-S21 & 181.6 & 34.3 & 0.26 & 70.8 & 135 & 17.0 & 9.5 & 2357 & 8999 & 11.3 & 91.4 & 8.0 & 24.3 \\
\hline S22 & 181.8 & 22.8 & 0.24 & 67.4 & 178 & 16.8 & 7.5 & 1719 & 3604 & 6.1 & 17.3 & 0.7 & 3.0 \\
\hline $\mathrm{S} 23$ & 206.0 & 26.2 & 0.28 & 63.1 & 220 & 17.3 & 6.4 & 1799 & 4366 & 17.4 & 36.5 & 0.1 & 1.4 \\
\hline Ave. & 218.7 & 28.2 & 0.30 & 68.1 & 165 & 16.0 & 8.2 & 2210 & - & 40.4 & - & 3.7 & - \\
\hline \multicolumn{14}{|c|}{ CS } \\
\hline $\mathrm{C} 7$ & 139.0 & 34.9 & 0.21 & 69.6 & 235 & 18.5 & 6.7 & 1724 & 7604 & 2.3 & 12.5 & 4.7 & 10.4 \\
\hline $\mathrm{C} 8$ & 195.9 & 24.0 & 0.27 & 68.5 & 241 & 16.6 & 6.7 & 3132 & 7782 & 10.2 & 29.3 & 2.6 & 33.1 \\
\hline $\mathrm{C} 9$ & 200.5 & 24.0 & 0.28 & 69.0 & 203 & 15.4 & 7.0 & 3564 & 7915 & 3.2 & 11.3 & 1.1 & 13.0 \\
\hline $\mathrm{C} 14$ & 212.4 & 19.1 & 0.28 & 67.6 & 219 & 15.5 & 6.5 & 3592 & 8571 & 16.8 & 36.2 & 3.6 & 95.0 \\
\hline C15 & 194.9 & 28.5 & 0.25 & 68.5 & 227 & 16.4 & 6.3 & 3238 & 8005 & 10.6 & 31.3 & 1.2 & 19.0 \\
\hline $\mathrm{C} 16$ & 195.1 & 23.0 & 0.23 & 67.9 & 166 & 16.4 & 8.0 & 1774 & 6023 & 6.7 & 17.3 & 0.8 & 4.6 \\
\hline $\mathrm{C} 17$ & 213.8 & 25.9 & 0.27 & 63.9 & 218 & 17.0 & 6.6 & 2053 & 6939 & 19.1 & 44.7 & 0.7 & 11.2 \\
\hline Ave. & 193.1 & 25.6 & 0.26 & 67.8 & 215 & 16.6 & 6.8 & 2725 & - & 9.8 & - & 2.1 & - \\
\hline
\end{tabular}

Concentrations reported are at pressure, temperature and $\mathrm{O}_{2}$ levels within the stack (not normalized at $\mathrm{O}_{2}$ reference). Average stack temperatures were 219 and $193{ }^{\circ} \mathrm{C}$ for WS and CS, respectively. Average primary air mass flow was 0.30 and $0.26 \mathrm{~kg} / \mathrm{s}$, respectively. Combustion efficiency was calculated by the analyzer based on measured parameters. Similar combustion efficiencies of about $68 \%$ were obtained for WS and CS. Excess air ratio was higher for CS, averaging at 215\% compared to $165 \%$ for WS. Average oxygen levels were around $16 \%$ for both biomasses, which is higher than normally observed in literature (between $5 \%$ and $8 \%$ for a continuously fed grate furnace [18]). Since the combustion process is a batch type and fuel-air contact was not homogenous, higher excess 
of air for CS did not reduce CO level compared to WS (2725 vs. $2210 \mathrm{mg} / \mathrm{m}^{3}$ ). Average $\mathrm{NO}_{x}$ and $\mathrm{SO}_{2}$ were 40.4 and $3.7 \mathrm{mg} / \mathrm{m}^{3}$ for WS and 9.8 and $2.1 \mathrm{mg} / \mathrm{m}^{3}$ for CS, respectively. The combustion of CS in a bale boiler has demonstrated higher levels of $\mathrm{CO}$, but lower levels of $\mathrm{SO}_{2}$ and $\mathrm{NO}_{x}$, when compared to continuous combustion of CS pellets in a pellet boiler where $\mathrm{CO}, \mathrm{SO}_{2}$ and $\mathrm{NO}_{x}$ were 54,100 and $252 \mathrm{mg} / \mathrm{m}^{3}$, respectively [22]. However, there is no Canadian legislation regarding in-stack emission limits for $\mathrm{CO}$, $\mathrm{NO}_{x}$, and $\mathrm{SO}_{2}$, but only for surrounding air quality. Beauchemin and Tampier [23] reported that German legislation for small 50-100 kW straw furnaces built before 2008 limits CO emissions to less than $2000 \mathrm{mg} / \mathrm{m}^{3}$; the limitation is reduced as furnace output power increases. The $\mathrm{NO}_{x}$ concentration is limited to $200 \mathrm{mg} / \mathrm{m}^{3}$ for wood furnace under $2 \mathrm{MW}$ (at $11 \%$ vol. $\mathrm{O}_{2}$ ). The Farm 2000 boiler would meet the German requirement for $\mathrm{NO}_{x}$ but not for $\mathrm{CO}$. A more efficient combustion could be obtained by adding an oxygen sensor within the stack to vary primary air flow.

Figures 3 and 4 show typical flue gas emissions for WS and CS. Oxygen level in exhaust gases was lower for the first $2 \mathrm{~h}$ and then increased to normal concentration (around 20\%) when less biomass was available for combustion according to primary air input. CO levels are relatively stable for the first $2 \mathrm{~h}$ and then decrease (for a single bale batch). Higher concentrations of $\mathrm{NO}_{x}$ were generally observed when $\mathrm{O}_{2}$ was lower, particularly for WS (about 20 to $100 \mathrm{mg} / \mathrm{m}^{3}$ of $\mathrm{NO}_{x}$ ) and stover (10 to $30 \mathrm{mg} / \mathrm{m}^{3}$ of $\mathrm{NO}_{x}$ ).

Figure 3. Typical flue gas emission concentrations for WS (bale S1 shown).

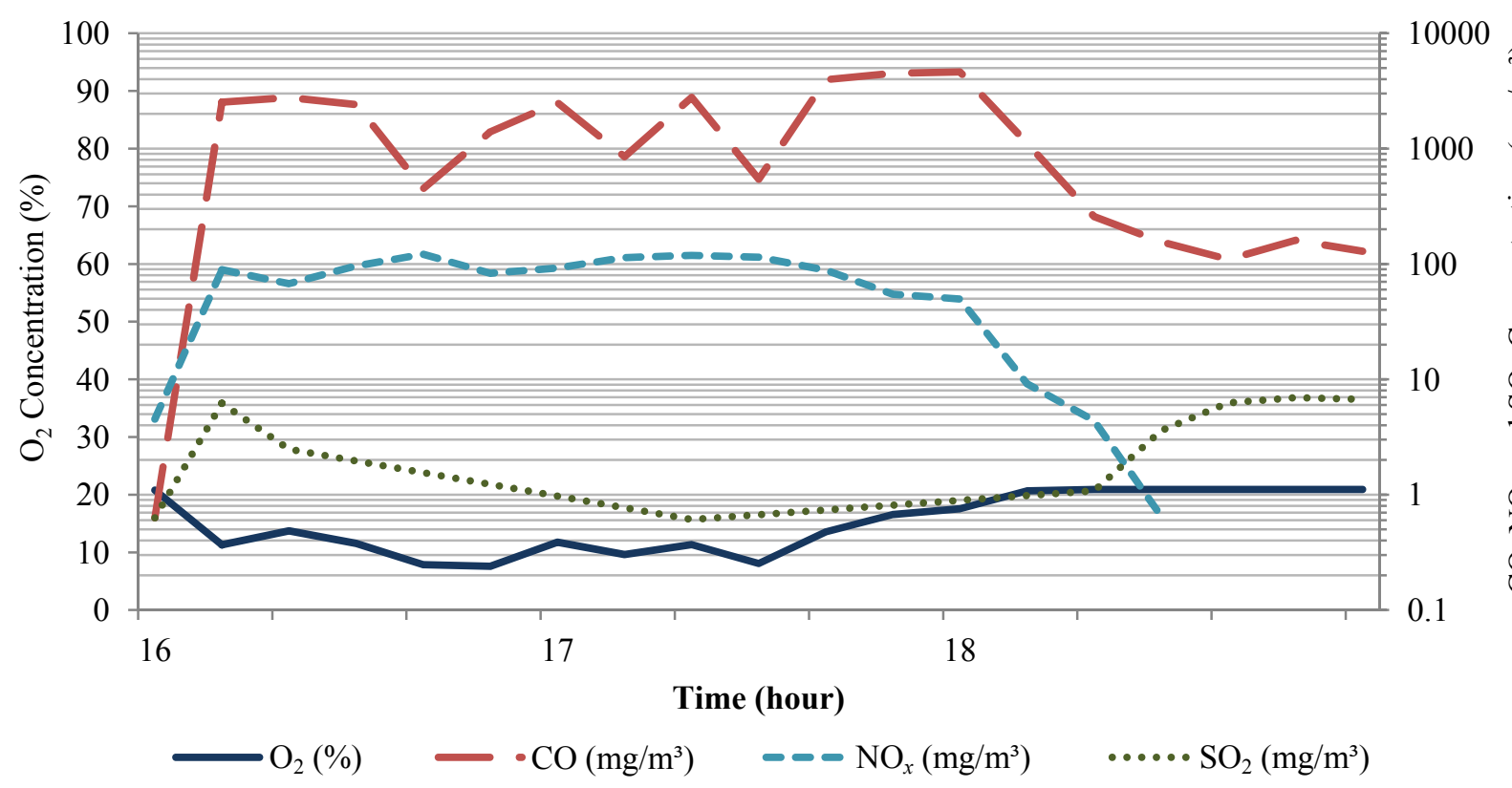


Figure 4. Typical flue gas emission concentrations for CS (bale C14 shown).

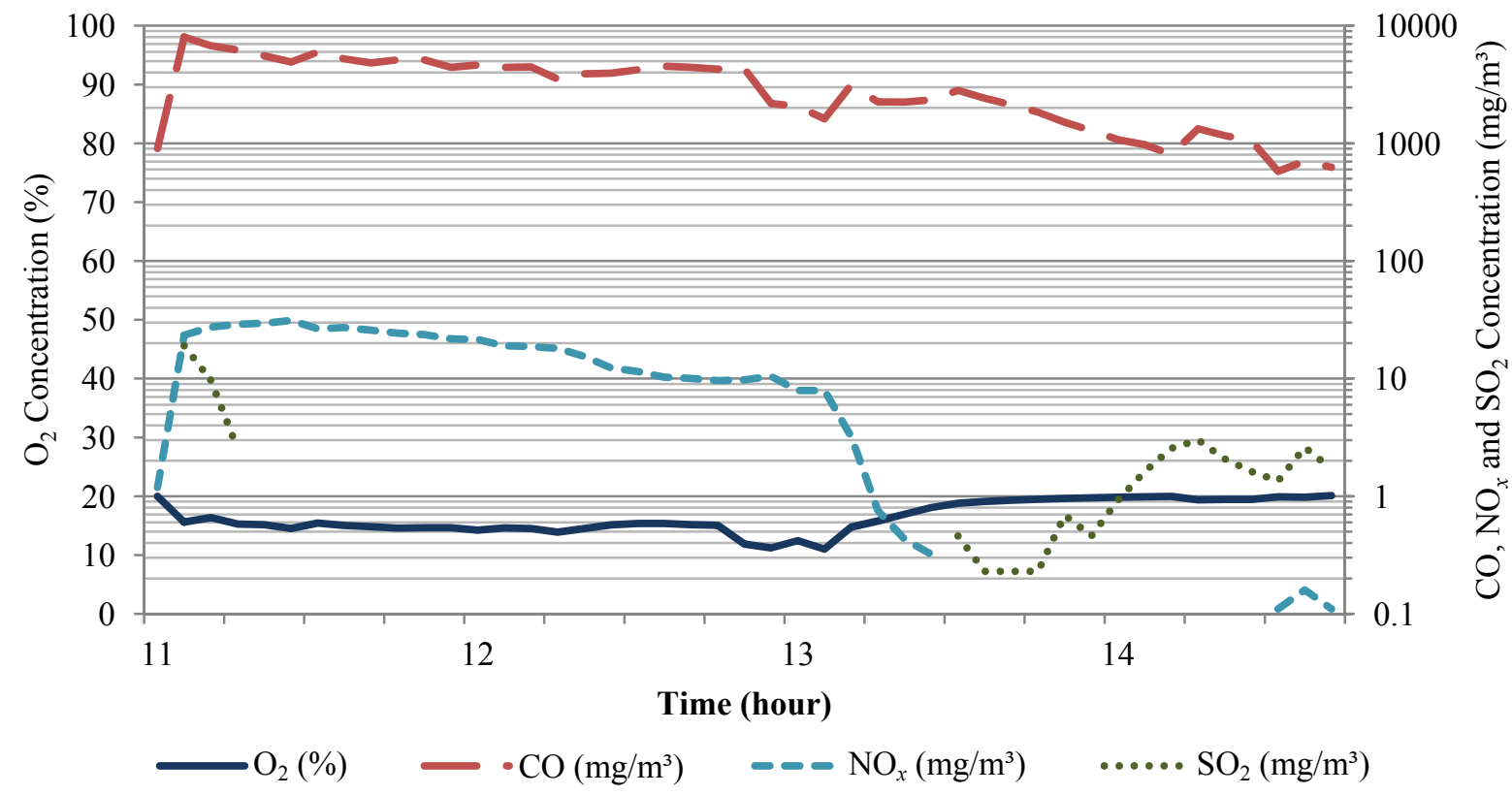

\subsection{Energy Balance}

Table 5 shows energy balance for each trial. Losses were calculated by difference as described in Equation 1. Thermal efficiency is the ratio of accumulated and output energies over total fuel energy (biomass NCV). For WS, total bale energy content was 16,216 MJ. About 9500 MJ (59\%) were transferred from the hot water tank to the barn's plate heat exchanger and $1400 \mathrm{MJ}$ were accumulated at the end of the trial. Total losses (by difference) were $5190 \mathrm{MJ}$ for an overall thermal efficiency of $68 \%$. With an operation period of $1680 \mathrm{~min}(28 \mathrm{~h})$, the average output power of the boiler was $108 \mathrm{~kW}$. For CS, total bale energy content was 30,481 MJ. Energy transferred to the heat exchanger was 13,332 MJ (about $44 \%$ of total NCV) while energy accumulated in the tank was -960 MJ (less energy than initially available). Total losses were calculated at 18,036 MJ with a thermal efficiency of $40.8 \%$. The average output power was only $68 \mathrm{~kW}$ based on a $3060 \mathrm{~min}(52 \mathrm{~h})$ trial duration. In all cases, there was no significant energy accumulation in the boiler water jacket itself. The thermal efficiency differences between CS and WS can partially be explained by the bale characteristics and the boiler design. As the CS bales were denser, less biomass area was in contact with the primary airflow to make them burn properly compared to lower density WS bales. According to the gas analyzer data, excess air ratio was higher for CS $(215 \%$ vs. 165\%) which may lower the combustion temperature in the combustion chamber $\left(193{ }^{\circ} \mathrm{C}\right.$ for CS vs. $219{ }^{\circ} \mathrm{C}$ for WS, see Table 4), and affects simultaneously the boiler's thermal efficiency, operational reliability and environmental performance (emissions from the unit) [24]. The Industrial Boiler Owners indicates that boiler efficiency can be increased by $1 \%$ for each $15 \%$ reduction in excess air [25]. It has also been demonstrated in the literature that biomass fuels with high ash content will produce more fly ash that may deposit on the surface of boiler tubes, which decrease the efficiency of heat transfer in the boiler [26]. A soot layer of $0.8 \mathrm{~mm}$ thick can reduce heat transfer by as much as $12 \%$ [27]. For biomass fuels with high ash content it is best to have an automatic heat exchanger cleaning system to maintain boiler efficiency. 
Table 5. Energy balance for WS and CS 2012 combustion trials.

\begin{tabular}{ccccccc}
\hline \multirow{2}{*}{$\begin{array}{c}\text { Biomass } \\
\text { type }\end{array}$} & Biomass & Boiler & \multicolumn{2}{c}{ Tank } & Total losses & Thermal \\
\cline { 2 - 7 } & $\mathbf{N C V}$ & $\begin{array}{c}\text { Accumulated } \\
\text { (MJ) }\end{array}$ & $\begin{array}{c}\text { Output } \\
(\mathbf{M J})\end{array}$ & $\begin{array}{c}\text { Accumulated } \\
(\mathbf{M J})\end{array}$ & $\begin{array}{c}\text { (By difference) } \\
(\mathbf{M J})\end{array}$ & $\begin{array}{c}\text { Efficiency } \\
(\%)\end{array}$ \\
\hline $\mathrm{WS}$ & 16,216 & 117.7 & 9,509 & 1,400 & 5,190 & 68.0 \\
$\mathrm{CS}$ & 30,481 & 72.8 & 13,332 & -960 & 18,036 & 40.8 \\
\hline
\end{tabular}

\subsection{Combustion Validation Trials Results}

Table 6 reports data for three 30-bale validation combustion trials in 2013 with CS. Most of the time, combustion was conducted with a single bale at a time. However, two bales at a time were put in the boiler in some cases, especially during the night. Average bale mass was $175.4 \mathrm{~kg}(153.5 \mathrm{~kg} \mathrm{DM})$ and moisture content was $12.5 \%$. With an average diameter and width of $1.4 \mathrm{~m}$ and $1.22 \mathrm{~m}$, respectively, the dry matter density of CS bales in 2013 was $82.7 \mathrm{~kg} \mathrm{DM} / \mathrm{m}^{3}, 21 \%$ lower than density of CS bales in $2012\left(104.5 \mathrm{~kg} \mathrm{DM} / \mathrm{m}^{3}\right)$. The first validation trial was conducted over a nine-day period where the average combustion period per bale was $412 \mathrm{~min}$ and average combustion rate was $27.1 \mathrm{~kg} \mathrm{DM} / \mathrm{h}$. Trial 2 in 2013 was done over an effective period of 14 days. The average combustion time per bale was higher than trial 1 with $624 \mathrm{~min} / \mathrm{bale}$. Thus, the average combustion rate was lower at $19.0 \mathrm{~kg} \mathrm{DM} / \mathrm{h}$. For the third trial, 12 days were necessary to burn the last 30 bales. The average interval between two bale loadings was longer $(671 \mathrm{~min})$ but the combustion rate was about the same as trial $2(19.5 \mathrm{~kg} \mathrm{DM} / \mathrm{h})$. These differences may be explained by the lower heating need during trial 3 (higher outdoor temperature) and longer overnight periods without loading.

Table 6. Average data for 30-bale CS combustion validation (2013 trials).

\begin{tabular}{|c|c|c|c|c|c|c|c|c|}
\hline \multirow{2}{*}{ Trial } & \multirow{2}{*}{$\begin{array}{c}\text { MC } \\
\%\end{array}$} & \multicolumn{2}{|c|}{ Bale mass } & \multirow{2}{*}{ Start date } & \multirow{2}{*}{ End date } & \multirow{2}{*}{$\begin{array}{c}\text { Duration } \\
\mathrm{min} / \mathrm{bale}\end{array}$} & \multirow{2}{*}{$\frac{\text { Burning rate }}{\mathrm{kg} \mathrm{DM} / \mathrm{h}}$} & \multirow{2}{*}{$\frac{\text { Ext. temp. }}{{ }^{\circ} \mathrm{C}}$} \\
\hline & & kg & kg DM & & & & & \\
\hline 1 & 13.3 & 182.4 & 158.1 & $2013-01-30$ & 2013-02-08 & 412 & 23.0 & -4.7 \\
\hline $2^{a}$ & 12.4 & 176.4 & 154.5 & $2013-02-17$ & $2013-03-23$ & 624 & 14.8 & -2.3 \\
\hline 3 & 11.7 & 167.5 & 147.9 & $2013-04-12$ & $2013-04-23$ & 537 & 16.5 & 6.1 \\
\hline Ave. & 12.5 & 175.4 & 153.5 & - & - & 524 & 17.6 & -0.3 \\
\hline
\end{tabular}

a: Trial 2 was interrupted from 26 February until 17 March for mechanical maintenance (broken pump).

Compared to the 2012 trial, bales in 2013 were lighter (153.5 vs. $164.5 \mathrm{~kg} \mathrm{DM})$, had a lower density ( 82.7 vs. $104.4 \mathrm{~kg} \mathrm{DM} / \mathrm{m}^{3}$ ), and had a slightly lower moisture content (12.5 vs. 13.6\%). Average combustion time per bale in 2013 was more than double and burning rate was half the value obtained in 2012. Even if average outdoor temperature was similar $\left(0 v s .-0.3{ }^{\circ} \mathrm{C}\right)$, energy consumption was lower than in the 2012 trial. According to the farmer, more birds were placed in the barn, thus generating more of their own heat. Also, ventilation was improved, which keeps the barn drier, and less heat was required.

Table 7 reports total mass burned and ash produced in 2013. The average dry matter burned during each trial was $4605 \mathrm{~kg}$ over an average period of $262 \mathrm{~h}$ of continuous operation. Ash collected in 2013 represented $7.90 \%, 5.75 \%$ and $4.93 \%$ d.b. of total mass burned for trial 1, 2 and 3, respectively. The average 2013 CS ash content was lower (6.19\%) than the 2012 CS ash content (9.17\%); it was 
still higher than 2012 WS ash content (1.7\% and 2.55\% for PCT and individual bale trial, respectively). The average ash production rate with CS in 2013 was three times lower than in the CS 2012 trial (1.09 vs. $3.48 \mathrm{~kg} / \mathrm{h})$ but only twice more than WS (0.56 kg/h weighted average). Burning CS will require more maintenance than WS. However, with good production management practices (i.e., barn ventilation, flock size, clean stover harvest), biomass consumption can be lowered as well as boiler maintenance.

Table 7. Ash content and production rate for CS (2013 trials).

\begin{tabular}{ccccccc}
\hline \multirow{2}{*}{ Trial } & \multirow{2}{*}{ Bales burned } & Total mass burned & Accumulation period & Ash content & Ash production rate \\
\cline { 2 - 7 } & & kg DM & $\mathbf{h}$ & $\mathbf{k g}$ & $\mathbf{\%} \mathbf{d . b .}$ & $\mathbf{~ k g} / \mathbf{h}$ \\
\hline 1 & 30 & $4,743.2$ & 206.2 & 374.6 & 7.90 & 1.82 \\
2 & 30 & $4,634.0$ & 312.2 & 266.4 & 5.75 & 0.85 \\
3 & 30 & $4,437.9$ & 268.3 & 219.0 & 4.93 & 0.82 \\
Ave. & 30 & $4,605.0$ & 262.2 & 286.7 & 6.19 & 1.09 \\
Sum & 90 & $13,815.0$ & 786.7 & 860.0 & - & - \\
\hline
\end{tabular}

\section{Conclusions}

Combustion trials of WS and CS bales in two consecutive years in a Farm 2000 commercial boiler showed differences between biomass characteristics, energy balance, ash content and flue gas emissions. Both biomasses were relatively dry (14.6\% and 13.6\%), but CS bales harvested in 2011 with a variable chamber baler were $35 \%$ denser than WS bales harvested with a fixed chamber baler (104.5 vs. $\left.77.1 \mathrm{~kg} \mathrm{DM} / \mathrm{m}^{3}\right)$. CS bales harvested in 2012 with a fixed chamber baler had an average density of $82.7 \mathrm{~kg} \mathrm{DM} / \mathrm{m}^{3}$ which resulted in a more complete combustion with less ash and unburned residues. The heating system's overall thermal efficiency was $68 \%$ with WS and $41 \%$ with high density CS in the first year. Ash content of CS was considerably higher than ash in WS in 2012 (9.2\% for CS vs. $1.7 \%$ for a pre-combustion trial of WS and $2.55 \%$ for individual WS bale combustion trials in 2012). The lower density CS bales in the second year produced one third less ash and unburned residue $(6.2 \%)$ than in the previous year with high density CS bales. The highest CO levels were observed with CS in the first year (average of $2725 \mathrm{mg} / \mathrm{m}^{3}$ with a peak at $8571 \mathrm{mg} / \mathrm{m}^{3}$ ) while $\mathrm{NO}_{x}$ emissions were higher for WS (40.4vs. $\left.9.8 \mathrm{mg} / \mathrm{m}^{3}\right)$. The limited insulation, heat losses in the flue gas, the high ash content of the biomasses and the basic combustion process controller (mainly for oxygen input) contributed to reduce overall system efficiency. Thus, the Farm 2000 has good potential for heat production using baled CS as a complementary energy source to WS if special attention is focused on harvesting methods to reduce ash content and to maintain low-to-medium bale density. These trials also highlighted the importance of using combustion technologies that are adapted to solid fuels in order to achieve lower emissions and higher thermal efficiency.

\section{Acknowledgments}

Authors acknowledge Agriculture and Agri-Food Canada (AAFC) and Natural Resources Canada through the Canadian Bioenergy Innovation Network for supporting this research. They also thank Tim Ansems for his excellent collaboration and access to his installations. 


\section{Conflicts of Interest}

The authors declare no conflict of interest.

\section{References}

1. Agriculture and Agri-Food Canada. Canada: Outlook for Principal Field Crops. Available online: http://www.agr.gc.ca/pol/mad-dam/index_e.php?s1=pubs\&s2=fco-ppc\&s3=php\&page=fco-ppc 2013-04-17 (accessed on 17 April 2013).

2. Lal, R. The role of residue management in sustainable agricultural systems. J. Sustain. Agric. 1995, 5, 51-78.

3. Wilhelm, W.W.; Johnson, J.M.E.; Karlen, D.L.; Lightle, D.T. Corn stover to sustain soil organic carbon further constrains biomass supply. Agron. J. 2007, 99, 1665-1667.

4. Lockeretz, W. Crop residues for energy: Comparative costs and benefits for the farmer, the energy facility, and the public. Energy Agric. 1982, 1, 71-89.

5. English, A.; Tyner, W.E.; Sesmero, J.; Owens, P.; Muth, D.J. Environmental tradeoffs of stover removal and erosion in Indiana. Biofuels Bioprod. Bioref. 2013, 7, 78-88.

6. Kludze, H.; Deen, B.; Weersink, A.; van Acker, R.; Janovicek, K.; De Laporte, A.; McDonald, I. Estimating sustainable crop residue removal rates and costs based on soil organic matter dynamics and rotational complexity. Biomass Bioenergy 2013, 56, 607-618.

7. Taheripour, F.; Tyner, W.E.; Fiegel, J. Development of Corn Stover Biofuel: Impacts on Corn and Soybean Markets and Land Rotation. In Proceedings of the Agricultural \& Applied Economics Association's AAEA \& CAES Joint Annual Meeting, Washington, DC, USA, 4-6 August 2013.

8. Bennett, A.S.; Bern, C.J.; Richard, T.L.; Anex, R.P. Corn grain drying using corn stover combustion and CHP systems. Trans. ASABE 2007, 50, 2161-2170.

9. Villeneuve, J.; Palacios, J.H.; Savoie, P.; Godbout, S. A critical review of emission standards and regulations regarding biomass combustion in small scale units $(<3 \mathrm{MW})$. Bioresour. Technol. 2012, 111, 1-11.

10. Leino, T.J.; Aho, M.J.; Gynther, S.J.; Ruuskanen, T.A.; Häkkinen, M.H. Experiences from a novel sensor for fireside corrosion monitoring during grate combustion of corn stover/wood chip blends. Energy Fuels 2013, 27, 5653-5662.

11. Leiser, S.; Cieplik, M.K.; Smit, R. Slagging behavior of straw and corn stover and the fate of potassium under entrained-flow gasification conditions. Energy Fuels 2012, 27, 318-326.

12. Lizotte, P.-L.; Savoie, P. Spring harvest of corn stover. Appl. Eng. Agric. 2011, 27, 697-703.

13. Sumner, H.R.; Sumner, P.E.; Hammond, W.C.; Monroe, G.E. Indirect-fired biomass furnace test and bomb calorimeter determinations. Trans. ASAE 1983, 26, 238-241.

14. Teisen Products Ltd. Farm 2000. Available online: http://www.farm2000.co.uk (accessed on 1 May 2013).

15. Lizotte, P.-L.; Savoie, P. Spring harvest of corn stover for animal bedding with a self-loading wagon. Appl. Eng. Agric. 2013, 29, 25-31.

16. Solid Biofuels. Determination of Calorific Value; Standard Number BS EN 14918:2009; British Standards Institution: London, UK, 2010. 
17. Standard Test Methods for Proximate Analysis of Coal and Coke by Macro Thermogravimetric Analysis; ASTM D7582-10; ASTM International: West Conshohocken, PA, USA, 2010.

18. Van Loo, S.; Koppejan, J. The Handbook of Biomass Combustion and Co-firing; Earthscan: London, UK, 2008.

19. BIOBIB - A Database for Biofuels. Available online: http://cdmaster2.vt.tuwien.ac.at/biobib/ biobib.html (accessed on 20 March 2012).

20. Schmidt, A.; Zschetzsche, A.; Hantsch-Linhart, W. Analyse von biogenen Brennstoffen; TU Wien, Institut für Verfahrens-, Brennstoff- und Umwelttechnik: Vienna, Austria, 1993.

21. Morissette, R.; Savoie, P.; Villeneuve, J. Combustion of corn stover bales in a small 146-kW boiler. Energies 2011, 4, 1102-1111.

22. Xiong, S.; Burvall, J.; Orberg, H.; Kalen, G.; Thyrel, M.; Ohman, M.; Boström, D. Slagging characteristics during combustion of corn stovers with and without kaolin and calcite. Energy Fuels 2008, 22, 3465-3470.

23. Beauchemin, P.A.; Tampier, M. Emissions from Wood-Fired Combustion Equipment; Envirochem Services Inc: North Vancouver, BC, Canada, 2008.

24. Basu, P.; Cen, K.F.; Jestin, L. Boilers and Burners; Springer: New York, NY, USA, 2000.

25. Guide to Low-Emission Boiler and Combustion Equipment Selection; ORNL/TM-2002/19; Oak Ridge National Laboratory (ORNL): Oak Ridge, TN, USA, 2002.

26. Biedermann, F.; Obernberger, I. Ash-Related Problems during Biomass Combustion and Possibilities for a Sustainable Ash Utilization; Elsevier Ltd.: Oxford, UK, 2005.

27. Cleaver-Brooks. Boiler Efficiency Guide. Available online: http://www.cleaver-brooks.com/ uploadedFiles/Internet_Content/Reference_Center/Insights/Boiler\%20Efficiency\%20Guide.pdf (accessed on 14 October 2013).

(C) 2013 by the authors; licensee MDPI, Basel, Switzerland. This article is an open access article distributed under the terms and conditions of the Creative Commons Attribution license (http://creativecommons.org/licenses/by/3.0/). 